\title{
Feeding and Healthcare Management Practices Adopted by Sheep Farmers in Karauli District of Eastern Rajasthan, India
}

\author{
Bacchu Singh $^{1 *}$, G.S. Meena ${ }^{2}$, K.C. Meena ${ }^{3}$ and Navab Singh ${ }^{4}$ \\ ${ }^{1}$ Krishi Vigyan Kendra, Hindaun, Rajasthan, India \\ ${ }^{2}$ Krishi Vigyan Kendra, Bundi, Rajasthan, India \\ ${ }^{3}$ Krishi Vigyan Kendra, Swaimadhopur, Rajasthan, India \\ ${ }^{4}$ Krishi Vigyan Kendra, Jhalawar, India
}

*Corresponding author

\section{A B S T R A C T}

\section{Keywords}

Feeding practices,

Healthcare

Practices, Sheep

Article Info

Accepted:

04 January 2018

Available Online:

10 February 2018
Sheep is an important source of livelihood for resource poor farmers in rural areas of semiarid region of Rajasthan. Adoption of improved sheep management practices bears pivotal role to improve the livelihood in such marginalised environments. This study was carried out to assess the adoption of feeding and healthcare management practices by sheep farmers. A questionnaire survey was undertaken with 200 sheep farmers in 20 villages in Hindon and Nadoti blocks of District Karauli Rajasthan to obtain the first hand information on feeding and healthcare management practices followed by sheep farmers. The study revealed that animals were mostly grazing on community land/public range land for about 4-8 h in a day. The concentrate was offered to lactating ewes' only@150$200 \mathrm{~g} / \mathrm{head} /$ day. They were not supplemented with concentrate mixture during critical stages of growth and advance pregnancy. Results further indicated that the adoption of overall scientific feeding and vaccination programme were satisfactory but practices like to control ecto and endo-parasite, naval cord disinfection, feeding mineral mixture, green fodder and treatment of sick animals by veterinary officer were poor and needs to improve a lot.

\section{Introduction}

The role of livestock is increasing in Indian economy. It contributed to nearly 16 per cent of total income from agriculture in 1970-71, which increased to over 25 per cent in 200203 (Meena and Singh 2013). This will continue to be so in the coming period due to various economic factors like increase in the population, urbanization and per capita income growth. The Animal Husbandry and livestock sectors are critical for the rural economy, especially the small and marginal farmers. They not only contribute to their income but also their best insurance against any natural calamity. The role of livestock is much pronounced in the arid and semi-arid regions like Rajasthan, which is prone to drought and resultant crop failure. At the time of crop failure, livestock sector acts as a cushion on which the farmers can fall upon. As per Livestock Census 2012, Rajasthan had 
13.3 million cattle, 12.9 million buffalo, 9.08 million sheep and 21.67 million goats. The indigenous breeds of cows reared in the district include Gir, Nagori and some local non-descript animals. Among buffaloes, Murrah, Murrah type, Bhadhavary and nondescript types are commonly found in the district.

The sheep is one of the major livestock contributing to the livelihood security of farmers in Rajasthan. They can thrive well in adverse climatic conditions using sparse vegetation. In sheep population, India had $3^{\text {rd }}$ position in world followed by China and Australia and Rajasthan also had $3^{\text {rd }}$ position in India followed by Andhra Pradesh and Karnataka. The major sheep breeds in Rajasthan are Chokla, Nali, Marwari, Magra, Jaisalmeri, Malpura, Sonadi and Pugal. The sheep population of the District is near about 60,000 and the breeds mainly found in the District are Malpura, Marwari, Chokla and non-descript. Sheep production is still in hands of socially and economically backward people of the society for whom they act as a store of wealth of high liquidity, a resource for meeting the household nutritional security and a source of regular income. Various improved sheep management technologies were developed at the Central Sheep and Wool Research Institute, Avikanagar, Rajasthan and state Veterinary Universities to cater the needs of sheep farmers.

They pertained to the broad areas of breed management, nutrition, healthcare, reproduction and product management. Adoption of improved management practices is expected to increase the income of farmers. Adoption is the mental process through which an individual passes from hearing about an innovation to final adoption (Rogers 1983).The District Karauli is famous for its geographical specialties and having full of natural beauty and covered by Vindhyanchal and Aravali mountains. The information on feeding and healthcare management practices in respect of sheep District had not been documented. In this backdrop a systemic survey was undertaken to study the existing feeding and healthcare management practices followed by farmers for rearing of sheep under field conditions to document information and the resulting information will be useful for future policies for improvement of production potential of sheep.

\section{Materials and Methods}

The study was conducted in randomly selected 20 villages of Hindon and Nadoti blocks of Karauli District of eastern Rajasthan because it is the potential district for sheep production, availability of grazing area and vegetation for sheep production and having dense population of sheep. The study uses primary data collected from 200 sheep farmers belonging to 20 villages of above selected blocks. The respondents, village were selected purposively as they were selected on the basis of maximum number of Tribal, Special backward cast, scheduled cast and sheep population to be covered under the transfer of technology programme of Krishi Vigyan Kendra, Karauli. The information was received from respondents through questionnaires. The farmers were interviewed personally, group discussion and key informants survey were done to collect information on current status of feeding and healthcare management practices of sheep (Picture 1). Adoption of sheep production technologies by farmers was studied in the district. Information on grazing, feeding green fodder, concentrate, mineral mixture, watering and healthcare practices were collected through formal interviews using a structured questionnaire personally. On grazing practices information was collected on grazing land resources, type of grazing and grazing hours. The data were tabulated and percentage was calculated. 


\section{Results and Discussion}

Information pertaining to feeding and healthcare management practices being followed by sheep-owners in Hindon and Nadoti blocks of Karauli District of Rajasthan has been discussed in following sub heads.

\section{Feeding management practices}

Different types of technologies were generated for sheep nutrition. Sheep are mainly grazers. They never eat grown up trees. During rainy season different types of grasses are available for the grazing. In winters flocks are grazed on stubbles of post harvested feeds and from March to June they are fed on different types of shrubs. Fodder trees are also important source during summer season when the crop lands or the common pastures are devoid of vegetation (Jat et al., 2006). In the study area, sheep are reared on zero input system. Table 1 shows that $81 \%$ farmers adopted the extensive grazing system. These findings were in agreement with report of Kailash and Naruka (2015). Mostly community land resources were used for grazing (95\%) and only 5\% sheep breeders used their own lands. Similar finding were also observed by Tailor et al., (2006) and Kailash and Naruka (2015). The sheep were sent for grazing early in the morning in summer and late in winters. In rainy season grazing out time was depended on weather conditions. The mostly farmers 79 $\%$ graze their animals 4 to $8 \mathrm{hrs}$ and only $21 \%$ farmers spent time for grazing less than $4 \mathrm{hrs}$. These findings were in accordance with (Yadav and Tailor, 2010; Rao et al., 2013). In general grazing hours in winters was less than in summer probably due to the availability of good pasture in the nearby area after harvesting of crops as well as shorter day length (Behura et al., 2009). Furthermore, the adoption of the feeding green fodder was only $27 \%$. Majority of sheep farmers did not fed green fodder to their animals (Table 1).
Supplementary feeding was not a general practice, only pregnant females and male lambs were fed with some dry fodder. Farmers reported that feeding concentrate to pregnant sheep $49 \%$. Rao et al., (2013) observed that no respondents were providing pregnancy allowance and very few (4.55\%) are following the practice of lamb feeding. Over $71 \%$ of sheep farmers prepared home grown concentrate for feeding to sheep which comprised of Barley, Maize and wheat as such or in the form of gruel plus some salt. Mineral mixture was not provided to sheep by $88 \%$ sheep farmers. Rao et al., (2013) observed that no respondents were feeding mineral mixture to their animals. The reason for low adoption of mineral mixture feeding was lack of knowledge about its use. In this study the adoption of colostrum feeding practice was high (92\%). It is in conformation with Meena and Singh (2013). Major watering sources for small ruminants in District were village ponds, river, bore wells, public tanks, others house hold water tanks. Access to drinking water for animals is however one of the major problem shepherds face during summer months (Misra et al., 2007). According to Suresh et al., (2008) hygienic drinking water sources were limited and the farmers depended on open sources or traveled long distance in search of water.

This is an alarming situation as the respondents are not aware of the important management practices. The Animal Husbandry Department, Extension agencies should strive hard to change the attitude of the farmers and make them to adopt the best management and nutrition practices. These practices directly reflect on the profits of the enterprise. Better adoption of management practices makes the farming viable and sustainable. It is recommended that sheep raising farmers, extension workers, researchers, non-government organizations and other stakeholders need to support to 
disseminate the package of sheep production technologies to reach at the farmer's field. The demand of sheep meat is high in the urban areas with the increasing price therefore; sheep farming entrepreneurs need to be support by the stakeholders to transfer the available technologies up to the farmers' field level to boost up the farmers economy by raising sheep.

\section{Healthcare Practices}

Different types of healthcare management technologies were generated for the sheep production purpose. Diseases are the major source of economic loss to the sheep production. In intensive animal production system, diseases cause loss through mortality (Mathur and Dubey, 1994). About 15 to 20\% of sheep die due to various diseases in India. Grazing on wet areas, overfeeding, sudden change in climate and unhygienic condition of houses are the main reasons for diseases. Since sheep always live in flock immediate attention is required to check the spread of contagious diseases. In the study area, most common diseases were enterotoxaemia, sheep pox, foot and mouth disease (FMD), pneumonia and parasitic diseases. Simple health care measures viz. de-ticking and deworming will dramatically improve the flock performance Rao et al., (2013). The survey revealed that only $58 \%$ of farmers adopted the practice of vaccination. It was observed that the practice of vaccination was generally adopted at the time of migration of flock or if there was an outbreak in the nearby areas. In general, majority of farmers did not vaccinate the animals, although State Government Animal Health Department vaccinate free of cost/nominal cost, but breeders were generally not aware of it or showed no interest.

These observation agrees well with the finding of Pali Districts (Geerlings, 2001), whereas in Tonk District of Rajasthan, practice of vaccination was much higher than the present findings (Suresh et al., 2008). Naruka and Kailash (2015) observed that only $36.11 \%$ of farmers adopted the practice of vaccination. Rao et al., (2013) observed that $90 \%$ of the farmers' flocks are covered under vaccination programme. Higher adoption rate for vaccination could be the impact of extension programme undertaken by CSWRI, Avikanagar. This is suggestive of fairly high level of awareness in Farmers regarding protecting their animals by vaccination.

Picture.1 Healthcare management practices (De-worming in a Flock)

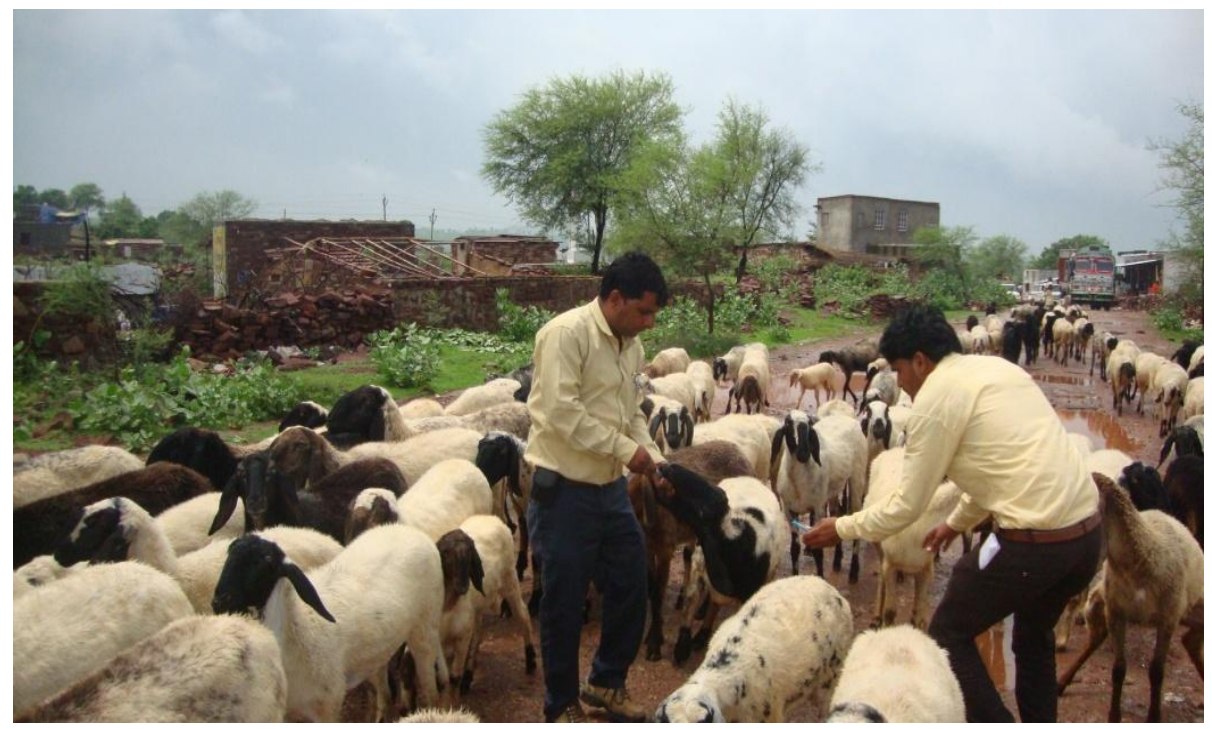


Table.1 Feeding management practices adopted by sheep farmers in Karauli District of eastern Rajasthan

\begin{tabular}{|c|c|c|c|}
\hline S. No. & Particulars & Frequently & Percentage \\
\hline \multirow[t]{3}{*}{1.} & \multicolumn{3}{|l|}{ Grazing System } \\
\hline & Extensive & 162 & 81 \\
\hline & Semi Extensive & 38 & 19 \\
\hline \multirow[t]{3}{*}{2.} & \multicolumn{3}{|l|}{ Grazing Site } \\
\hline & Own land & 10 & 5 \\
\hline & Community land & 190 & 95 \\
\hline \multirow[t]{3}{*}{3.} & Grazing Duration & & \\
\hline & $0-4$ hours & 42 & 21 \\
\hline & 4-8 hours & 158 & 79 \\
\hline \multirow[t]{3}{*}{4.} & Green Fodder Feeding & & \\
\hline & Yes & 54 & 27 \\
\hline & No & 146 & 73 \\
\hline \multirow[t]{9}{*}{5.} & \multicolumn{3}{|l|}{$\begin{array}{l}\text { Concentrate Feeding } \\
\text { A. For Kid }\end{array}$} \\
\hline & Yes & 82 & 41 \\
\hline & No & 118 & 59 \\
\hline & \multicolumn{3}{|c|}{ B. Special Feeding for lactating does } \\
\hline & Yes & 56 & 28 \\
\hline & No & 144 & 72 \\
\hline & \multicolumn{3}{|c|}{ C. Special Feeding during Pregnancy } \\
\hline & Yes & 98 & 49 \\
\hline & No & 102 & 51 \\
\hline \multirow[t]{3}{*}{6.} & \multicolumn{3}{|l|}{ Type of Concentrate } \\
\hline & Home Made & 142 & 71 \\
\hline & Purchased & 58 & 29 \\
\hline \multirow[t]{3}{*}{7.} & \multicolumn{3}{|c|}{ Feeding of Mineral Mixture } \\
\hline & Yes & 24 & 12 \\
\hline & No & 176 & 88 \\
\hline \multirow[t]{3}{*}{8.} & \multicolumn{3}{|l|}{ Colostrum Feeding } \\
\hline & Yes & 184 & 92 \\
\hline & No & 16 & 8 \\
\hline
\end{tabular}


Table.2 Healthcare management practices adopted by sheep farmers in

Karauli District of eastern Rajasthan

\begin{tabular}{|c|c|c|c|}
\hline S. No. & Particulars & Frequently & Percentage \\
\hline \multirow[t]{3}{*}{ 1. } & \multicolumn{3}{|l|}{ Vaccination of animals } \\
\hline & Yes & 116 & 58 \\
\hline & No & 84 & 42 \\
\hline \multirow[t]{4}{*}{2.} & \multicolumn{3}{|l|}{ De-worming of animals } \\
\hline & Regular & 50 & 25 \\
\hline & Occasional & 140 & 70 \\
\hline & Not Practiced & 10 & 5 \\
\hline \multirow[t]{3}{*}{3.} & \multicolumn{3}{|c|}{ Navel disinfection of Kid after birth followed } \\
\hline & Yes & 0 & 0 \\
\hline & No & 200 & 200 \\
\hline \multirow[t]{3}{*}{4.} & \multicolumn{3}{|c|}{ Practice to control ecto - parasites } \\
\hline & Followed & 80 & 40 \\
\hline & Not followed & 120 & 60 \\
\hline \multirow[t]{3}{*}{5.} & \multicolumn{3}{|c|}{ Sanitary condition of shelter/Standing place } \\
\hline & Clean (Dry) & 108 & 54 \\
\hline & Dirty (Wet) & 92 & 46 \\
\hline \multirow[t]{5}{*}{6.} & \multicolumn{3}{|l|}{ Treatment of sick animals } \\
\hline & Use of local empirical knowledge & 110 & 55 \\
\hline & Calling a quack & 10 & 5 \\
\hline & Para veterinarian & 50 & 25 \\
\hline & Veterinary doctor & 30 & 15 \\
\hline \multirow[t]{3}{*}{7.} & \multicolumn{3}{|l|}{ Use of Medicine } \\
\hline & Home made & 28 & 14 \\
\hline & By Doctor's Prescription & 172 & 86 \\
\hline
\end{tabular}

The most serious health problem of sheep was internal parasites. Helminthes are important endo-parasites of sheep. Several species of flat worms, tape worms and round worms are present in the digestive tract of sheep. It was observed that very few respondents $25 \%$ practiced de-worming to their animals at regular intervals. Whereas, $70 \%$ farmers followed de-worming occasionally to control endo-parasites. Naruka and Kailash (2015) observed that $90.55 \%$ of farmers adopted the practice of de-worming. Rao et al., (2013) observed that only 43.2 and $54.6 \%$ farmers are following de-ticking and de-worming. $100 \%$ de-worming was reported in Rajasthan and Telangana region of Andhra Pradesh by Swarnkar and Singh (2010), Mehta et al., (1995), Devendran et al., (2010) and Rajanna et al., (2013) respectively. Although regular de-worming is a good practice but overuse of drug can cause resistance. The low adoption for de-worming measures in study area may be due to lack of awareness. Ticks and lice are important ecto-parasites of small ruminants. Table 2 showed majority of sheep farmers $(60 \%)$ did not follow any practice to control ecto- parasite however, some farmers adopted traditional practices- like smoke of neem leaves to prevent mosquitoes. This practice needs attention to create awareness in 
sheep farmers covered under present study. Naruka and Kailash (2015) observed that $34.44 \%$ of farmers adopted the practice of control of ecto parasites. Rajanna et al., (2013) and Mehta et al., (1995) observed higher adoption (91.84\%). Ticks do not cause skin disease but are responsible for transmission of a few protozoans, bacterial and viral infection (Miranpuri and Singh, 1978). It was observed that none of the respondents followed practice of ligation and navel disinfection of kid after birth. It was left to fall off itself naturally. The similar findings were reported by Meena and Singh (2013). The survey revealed that only $40 \%$ of farmers adopted the clean dry shelter for sanitary practice of sheep housing.

It was also observed that majority of farmers $(55 \%)$ used local empirical knowledge in treatment their sick animals in their flocks. The $25 \%$ of sheep keepers preferred paraveterinarians for treatment of sick animals as they are locally available. Only $20 \%$ of the respondents acquired the services of a qualified veterinarian for treatment. Whereas, $5 \%$ respondents acquired the services of quacks. This may be due to the nonavailability of a qualified veterinarian. Rao et al., (2013) observed that 85\% farmers approach veterinary doctor or a paraveterinarians only occasionally. Most of the sheep farmers of the study area used local therapy for the treatment to their sheep.

These findings were in accordance with earlier reports of Swarnkar and Singh (2010). It was also observed that $14 \%$ breeders used homemade medicines for the treatment of their animals. Similar findings were observed by Naruka and Kailash (2015). Practice of some indigenous traditional knowledge for treatment of sheep was also reported by Behura et al., (2009). Sometimes these medicines cause serious problems due to higher dose and adverse effects.
Our study indicated that adoption of overall scientific practices was quite satisfactory. Adoption of regular vaccination against Bluetongue and FMD was good but very poor in other healthcare management practices like regular de-worming. Hence, these practices need to be improved to a great extent in this area. Lack of awareness and accessibility of veterinary service providers are the primary reasons. There is a dire need to strengthen the Animal Husbandry service sector through providing gross root level workers as most of the farmers are poor and cannot hire services of veterinarians. However, slow and concerted efforts must be made to stimulate affordable farmers to make use of paid veterinary clinics for efficient and timely service.

It is concluded that the extent of adoption of feeding and health care management practices followed by sheep farmers quite satisfactory. Adoption of overall scientific feeding practices and vaccination programme was good but practices like measures to control ecto and endo-parasite, naval cord disinfections, mineral mixture feeding and concentrate mixture feeding to kids and pregnant does was poor and needs to improve a lot. Hence, these practices need to be improved to a greater extent in this tribal area. Further, the results indicate need of extension activities for spreading improved management practices, institutional intervention for conservation of the common grazing land and improving the veterinary services to enhance the productivity of goats.

\section{References}

19th Livestock Census. 2012. All India Report, Department of Animal Husbandry, Dairying and Fisheries, Ministry of Agriculture, Government of India, Krishi Bhawan, New Delhi.

Behura NC, Parida GS, Mishra SK and Dehuri PK 2009. Contribution of small ruminants to 
sustainable livelihood of villagers in koraput district of Orissa. Indian Journal of Small Ruminants 15(1) 62-67.

Devendran P, Kandasamy N, Panneerselvam S and Thiruvenkadan AK 2010. Rearing environment and husbandry practices of Coimbatore sheep. Indian J. Anim. Sci. 80:470-472

Geerlings E 2001. Sheep husbandary and ethnoveterinary knowledge of Raika sheep pastoralists, MSc Thesis, Wageningen University, Deventer, The Netherlands.

Jat HS, Sharma SC, Mann JS and Singh VK 2006. Ardu: A miracle tree for semi-arid regions. CSWRI, Avikanagar.

Kailash and Naruka Kavita 2015. Grazing and housing practices of sheep in western Rajasthan. Cibtech Journal of Zoology. 4 (1):23-25

Mathur PB and Dubey SC 1994. Sheep and goat diseases. Indian Council of Agricultural Research, New Delhi.

Meena ML and Singh Dheeraj 2013. Adoption level of sheep farming practices in arid zone of Rajasthan, India. Indian J. Anim. Res. 47(5):397-401

Mehta SC, Vij PK, Nivsarkar AE and Sahai R 1995. Sheep husbandry practices in Sonadi and Malpura breeding tract. Indian Journal of Small Ruminants 1(1) 1-7.

Miranpuri GS and Singh J 1978. Tick and mites from domestic animals in Assam, India and their possible role in transmission of diseases. Indian Journal of Parasitology 2 11.

Misra AK, Ramana DBV, Prasad MS and Ramakrishna YS 2007. Feeding and management of small ruminants, $K V K$ Bulletin. Krishi Vigyan Kendra, Central
Research Institute for Dryland Agriculture, Hyderabad (2).

Naruka Kavita and Kailash 2015. Health care practices of sheep in Jodhpur District of Rajasthan. Indian Journal of Fundamental and Applied Life Sciences. 5(2):119-121

Rajanna N, Mahendar M, Thammiraju D, Nagalashami D and Sreenivasarao D 2013. Housing and health care management practices adopted by sheep farmers in Telangana region of Andhra Pradesh. Medwell Journals, Veterinary Research 6(3) 64-67.

Rao KA, Rao KS, Rao SJ, Ravi A and Anitha A 2013. Analysis of sheep production systems: North coastal zone of Andhra Pradesh. International Journal of Agriculture Science and Veterinary Medicine 1(3) 131-144.

Rogers, EM 1983. Diffusion of Innovations. The Free Press, New York: 132.

Suresh A, Gupta DC and Mann JS 2008. Farmers' management practices and economics of sheep farming in eastern semi-arid region of Rajasthan. Indian Journal of Small Ruminants 14(2) 236-242.

Swarnkar CP and Singh D 2010. Questionnaire survey on sheep husbandry and worm management practices adopted by farmers in Rajasthan. Indian Journal of Small Ruminants 16(2) 199-209.

Tailor SP, Nagda RK and Gupta L 2006. Characterization and evaluation of Sonadi sheep in its native tract. Indian Journal of Small Ruminants 12(2) 206-211.

Yadav CM and Tailor SP 2010. Grazing and housing practices of sheep in southern part of Rajasthan. Indian Journal of Small Ruminants 16(2) 287-289.

\section{How to cite this article:}

Bacchu Singh, G.S. Meena, K.C. Meena and Navab Singh. 2018. Feeding and Healthcare Management Practices Adopted by Sheep Farmers in Karauli District of Eastern Rajasthan, India. Int.J.Curr.Microbiol.App.Sci. 7(02): 309-316.

doi: https://doi.org/10.20546/ijcmas.2018.702.040 